\title{
Pupillary Functions and Wavefront Aberrations in Childhood Obesity
}

\author{
Çocukluk Çağı Obezitesinde Pupil Fonksiyonları ve Wavefront Aberasyonlar
}

\author{
Abdullah Ilhan', Umit Yolcu'2, Salih Altun', Uzeyir Erdem ${ }^{3}$ \\ ${ }^{1}$ Era Eye Center; ${ }^{2}$ Ankasu Eye Center; ${ }^{3}$ Independent Researcher, Ankara, Turkey
}

\begin{abstract}
Aim: The purpose of this study is to investigate the relationship between pupillary functions, wavefront aberrations, and childhood obesity.

Material and Method: Fifty-four obese children ( $\geq 95$ th body mass index percentile) were compared with 58 age- and gender-matched controls (<85th body mass index percentile) in this case-control study. Wavefront aberrations, mesopic and photopic pupil diameters were assessed by means of OPD-Scan II [Pupillometer/Corneal Wavefront Analyser]; [ARK-10000 system (Nidek, Japan)].
\end{abstract}

Results: Photopic pupil sizes in obese children were significantly smaller than the control group (3.68 \pm 0.64 (2.61-6.09), 4.83 \pm 0.63 (2.94-6.26) $\mathrm{mm} ; p<0.001)$. Mesopic pupil sizes in obese children were bigger than control group but it was not significant (6.88 \pm 0.58 (5.24-8.89), 6.65 \pm 0.77 (5.16-8.62) mm; p>0.05). Total optical aberrations were also significantly higher in obese children $(1.17 \pm 0.79,0.88 \pm 0.47 ; p<0.01)$. The other aberrations such as tetrafoil, trefoil, coma, and total high order aberrations were higher in obese children but these changes were insignificant.

Conclusion: This study showed an association between pupillary functions, total wavefront aberrations, and obesity. These data suggest that obesity might be an important risk factor for aberrations associated with diminished optical quality in children.

Key words: childhood obesity; ocular Wavefront aberration; pupil size

\section{ÖZET}

Amaç: Çalıșmanın amacı pupiller fonksiyonlar ve wavefront aberasyonların çocukluk çağı obezitesi ile arasındaki ilișkinin araștırılmasıdır.

Materyal ve Metot: Bu vaka kontrol çalıșmasında 54 obez çocuk (vücut kitle indeksi $\geq 95$ persentil), yaș ve cinsiyet uyumlu 58 kișilik kontrol grubu (vücut kitle indeksi <85 persentil) ile karșılaștırıld. Wavefront aberasyonlar ile fotopik ve mezopik pupil boyutu OPDScan II [Pupillometer/Corneal Wavefront Analyser]; [ARK-10000 system (Nidek, Japan)] ile tespit edildi.
Bulgular: Fotopik pupil boyutları obez çocuklarda kontrol grubuna

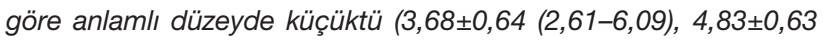
$(2,94-6,26 \mathrm{~mm}$, sırasıyla; $p<0,001)$. Mezopik pupil boyutları obez çocuklarda daha büyüktü ancak fark anlamlı değildi $(6,88 \pm 0,58$ $(5,24-8,89), 6,65 \pm 0,77(5,16-8,62) \mathrm{mm} ; \mathrm{p}>0,05)$. Toplam optik aberasyonlar obez çocuklarda anlamlı düzeyde yüksekti $(1,17 \pm 0,79$, $0,88 \pm 0,47 ; p<0,01)$. Coma, trefoil ve toplam üst sıra aberasyonları içeren diğer bütün aberasyonlar obez çocuklarda yüksek iken fark istatistiksel olarak anlamlı değildi.

Sonuç: Bu çalıșma pupiller fonksiyon, toplam wavefront aberasyonlar ve obezite arasında bir ilișkiyi göstermiștir. Bu veriler obezitenin, çocuklarda azalmıș optik kalite ile ilișkili aberasyonlar için önemli bir risk faktörü olabileceğini göstermiștir.

Anahtar kelimeler: çocukluk çağı obezitesi; oküler Wavefront aberasyon; pupil çapı

\section{Introduction}

The universal rate of childhood obesity and overweight has increased especially in the last several decades. The overall prevalence of obesity and overweight among children was $0.8 \%$ in 1975 but it is reported as $5.6 \%$ in girls and $7.8 \%$ in boys in $2016^{1}$. Childhood obesity may cause coronary artery disease, hyperlipidemia, atherosclerotic processes, diabetes mellitus, systemic hypertension, musculoskeletal system problems, some types of cancer, depression, obstructive sleep apnea, and low quality of life ${ }^{2,3}$. Childhood obesity also causes malfunctions in the autonomic nervous system (ANS) ${ }^{3-6}$.

Heart rate variability (HRV) is the basic and noninvasive method to gauge autonomic activity and related potential cardiac autonomic malfunction.

IIetișim/Contact: Abdullah Ilhan, Era Eye Center, Ankara, Turkey • Tel: 05458611118 • E-mail: dzilhan@hotmail.com • Geliș/Received: 01.06.2020 • Kabul/Accepted: 08.05.2021

ORCID: Abdullah İlhan, 0000-0002-9140-9527 • Ümit Yolcu, 0000-0002-2605-3413 • Salih Altun, 0000-0002-1609-2072 • Üzeyir Erdem, 0000-0002-3420-4365 
Regarding the HRV values of obese and normalweight adults, there are many studies reporting various results such as reduction in parasympathetic activity, decline in both sympathetic and parasympathetic pathways ${ }^{7-10}$ and increase in sympathetic activity $^{11-13}$. The other method of assessing ANS functions is pupillometry. Pupil size is supervised by the sympathetic and the parasympathetic systems together ${ }^{14}$. When the muscarinic receptors of the iris sphincter muscle meet with acetylcholine, the parasympathetic system becomes activated and causes miosis. On the other hand, nor-adrenalin discharge from the neuromuscular junction leads to mydriasis as a result of the sympathetic system. Briefly; the alterations in pupil diameter in regards to a light flash depend on the physiological balance between the parasympathetic and sympathetic mechanisms ${ }^{15}$. Thus, pupillometric measurements can reflect dysfunctions of $\mathrm{ANS}^{16,17}$. Pupillometry can be preferable because it's noninvasive, cheap, and easy to apply.

Ocular wavefront aberrations (WF), described as the diversion of light after it gets in the eye compared to an optically ideal eye model causing blurry images and diminished visual quality ${ }^{18,19}$. Aberrations are subclassified as low order aberrations that could be corrected with spectacles/sphero-cylindrical lenses and high order aberrations that could not.

As aberrations are closely related to pupil size, systemic disorders causing alterations in ANS may lead to both pupil and WF changes. The purpose of our case-control study is to explore the role of obesity on pupil sizes and WF aberrations in children.

\section{Material and Method}

Fifty-four obese children ( $\geq 95$ th BMI percentile) were compared with 58 age- and gender-matched controls (<85th BMI percentile) ${ }^{20}$. Overweight/ obese children were defined using age and genderspecific nomograms. Children in the study group had been obese for at least two years. All participants were prepubertal children. Diagnosis and follow up examinations of obese children were held by the department of pediatric endocrinology. Physical examinations and laboratory analysis for all participants proved the absence of any underlying systemic disease which might alter the autonomic and vascular systems. Fasting glucose, insulin, ALT, AST, GGT levels were analyzed and abdominal ultrasonography were performed in the obese group to exclude insulin resistance and hepatosteatosis. None of the participants had been taking any medicine. Patients with spherical refractive values between $-1.0 \mathrm{D}$ and $+1.0 \mathrm{D}$ and astigmatic refractive values under 1.0 D were accepted as a subject for the study.

For both groups, mesopic and photopic and pupil diameters, WF aberrations, were gauged by OPDScan II [Pupillometer/Corneal Wavefront Analyser]; [ARK-10000 system (Nidek, Japan)]. It operates an infrared detector to get an image and makes pupillometric calculations. OPD-Scan assessments are performed automatically. The first one is made during mesopic status and the second one is during photopic status. Poor quality measurements are ignored if detected by an automated quality control system. Measurements were taken between 1 and 3 pm after 15 minutes of rest. The pupil camera was utilized to get images of both (non-dilated) eyes in a silent and darkened room under two natural illumination status (mesopic: 10 lux, photopic: 100 lux). In this study, data of the right eyes were harvested for analysis. In order to avoid data duplication bias because of symmetricity, only one (right) eye of each subject was assessed.

This study was conducted on behalf of the permission of Gulhane Military Medical Academy Ethics Committee (Y. ETIK KRL. : 1491-367-07), Turkey and proceeded in harmony with international agreements and the Declaration of Helsinki. Parents were demanded to give informed consent after the procedure had been explained.

\section{Statistical Analyses}

Statistical Package for Social Sciences (SPSS) software version 15 was used to perform statistical analyses. To detect if the variables were normally distributed or not, they were analyzed by Shapiro-Wilk's test. Independent samples t-test or Mann-Whitney $U$ test was utilized depending on the result of the Shapiro-Wilk test. All values were indicated as mean \pm standard deviation. A possibility value of less than 0.05 was accepted as statistically significant.

\section{Results}

The mean age was $8.52 \pm 0.88(6-11)$ years in obese children and $8.66 \pm 0.54(6-11)$ years in the control group $(\mathrm{p}=0.21)$. Obese group was consisted of 29 (53.7\%) male/25 (46.3\%) female children and control 
group was consisted of 30 (51.7\%) male/28 (48.3\%) female children $(\mathrm{p}=0.34)$ (Table 1$)$.

In the obese group, mean photopic and mesopic pupil sizes were $3.68 \pm 0.64(2.61-6.09) \mathrm{mm}$ and $6.88 \pm 0.58$ (5.24-8.89) $\mathrm{mm}$ respectively. In the control group, mean photopic and mesopic pupil sizes were $4.83 \pm 0.63$ (2.94-6.26) $\mathrm{mm}$ and 6.65 $\pm 0.77(5.16-8.62) \mathrm{mm}$ respectively. Photopic pupil sizes in the obese group were significantly smaller, (Mann- Whitney -U test, $\mathrm{p}=0.0001$, ). Mesopic pupil sizes in the obese group were bigger but this was not statistically significant $(\mathrm{p}=0.20)$ (Figure 1).

The value of the central $3 \mathrm{~mm}$ root mean square (RMS), which is a quality indicator of the OPD measurements, was $0.2 \mu \mathrm{m}$. Total optical aberrations were significantly higher in obese children $(1.17 \pm 0.79,0.88 \pm 0.47$; $\mathrm{p}=0.02$ ). The other aberrations such as tetrafoil, trefoil, coma, spherical, and total high order aberrations were higher in obese children but these changes were insignificant (Table 2) (Figure 2).

Table 1. Demographic characteristics of the control and obese groups

\begin{tabular}{lcc}
\hline Demographic characteristics & Control group & Obese group \\
\hline Age (years) & $8.66 \pm 0.54(6-11)$ & $8.52 \pm 0.88(6-11)$ \\
Sex & & \\
$\quad$ Male & $30(51.7 \%)$ & $29(53.7 \%)$ \\
$\quad$ Female & $28(48.3 \%)$ & $25(46.3 \%)$ \\
\hline
\end{tabular}

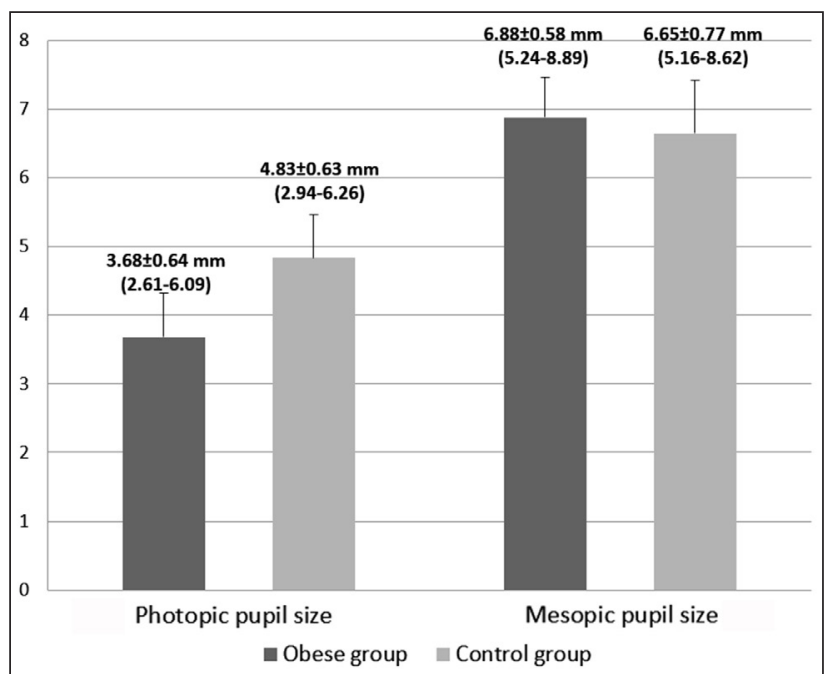

Figure 1. Photopic and mesopic pupil sizes in obese and control groups of children.

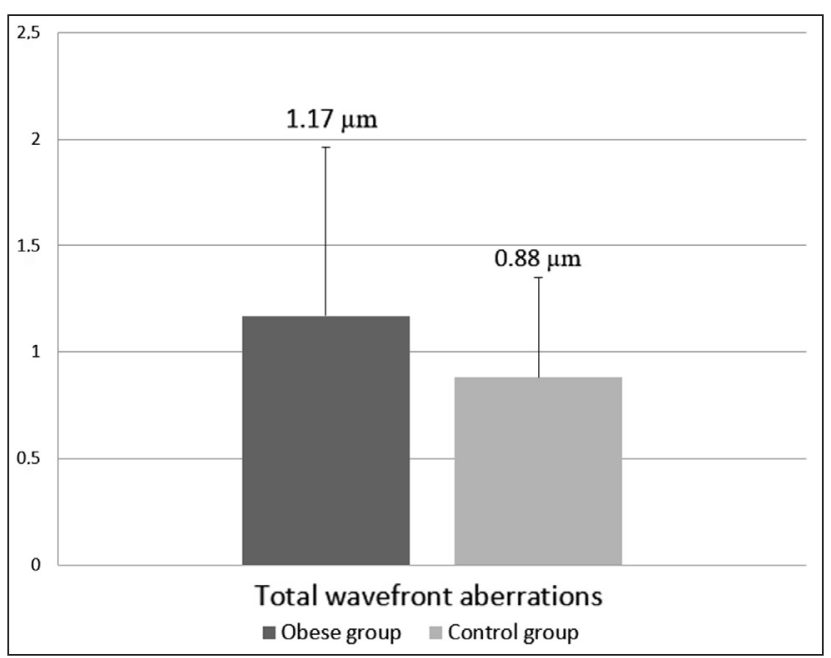

Figure 2. Comparison of total wavefront aberrations between obese and control groups.

Table 2. Photopic and mesopic pupil sizes and WF aberrations in obese and control groups of children.

\begin{tabular}{|c|c|c|c|}
\hline Pupil sizes and WF aberrations & Obese $n=54$ & Control $n=58$ & $p$ \\
\hline Photopic pupil size (mm) & $3.68 \pm 0.64(2.61-6.09)$ & $4.83 \pm 0.63(2.94-6.26)$ & $<0.001^{*}$ \\
\hline Mesopic pupil size (mm) & $6.88 \pm 0.58(5.24-8.89)$ & $6.65 \pm 0.77(5.16-8.62)$ & $0.20^{\star}$ \\
\hline RMS 1 (3 mm) & $0.21 \pm 0.08$ & $0.19 \pm 0.08$ & $0.14^{\star}$ \\
\hline RMS $2(5 \mathrm{~mm})$ & $0.34 \pm 0.21$ & $0.31 \pm 0.14$ & $0.96^{\star \star}$ \\
\hline Total & $1.17 \pm 0.79$ & $0.88 \pm 0.47$ & 0.02 ** \\
\hline Tilt & $0.44 \pm 0.29$ & $0.41 \pm 0.24$ & $0.82^{\star \star}$ \\
\hline High & $0.37 \pm 0.15$ & $0.33 \pm 0.10$ & $0.32^{\star *}$ \\
\hline T.coma & $0.19 \pm 0.13$ & $0.18 \pm 0.09$ & $0.93^{\star \star}$ \\
\hline T.tre & $0.22 \pm 0.12$ & $0.20 \pm 0.08$ & $0.81^{\star \star}$ \\
\hline T.4Foil & $0.07 \pm 0.07$ & $0.06 \pm 0.03$ & $0.57^{\star \star}$ \\
\hline TSph & $0.09 \pm 0.05$ & $0.09 \pm 0.06$ & $0.26^{\star \star}$ \\
\hline HiAstig & $0.06 \pm 0.04$ & $0.05 \pm 0.03$ & $0.53^{\star \star}$ \\
\hline
\end{tabular}

* Independent samples t test. *^ Mann-Whitney U-test.

RMS, root-mean-square values in microns are shown for a 3-mm and 5-mm pupil; Total, aberrations for the entire eye; High, higher-order aberration; T. Coma, total coma aberration; T.tre, total trefoil; T.4Foil, total quadrafoil; T.Sph, total spherical aberration; HiAstig, higher order astigmatism. 


\section{Discussion}

Obesity is well-known to be related to ANS dysfunction in adults and children ${ }^{4,13,21-2}$. There are several studies about multiple pediatric disorders related to ANF dysfunctions reporting remarkable pupillometric assessments ${ }^{23-7}$. Only Baum ${ }^{10}$ et al. used pupillometry for pediatric obesity. They studied obese children and adolescents in terms of ANS dysfunction by means of quantitative pupillography analysis, HRV, and sympathetic skin response. Unlike our results, they revealed a significant negative correlation between mesopic pupil size and BMI. But their study doesn't include WF aberrations.

Parasympathetic hypoactivity was reported in obese children and adults in the majority of the previous studies ${ }^{10,28-30}$. So it is more likely to face mydriasis in obese children due to relatively increased sympathetic activity. But, the photopic pupil sizes were found significantly smaller in the obese group in our study. Our result may be attributed to the development of cholinergic hypersensitivity of the iris sphincter muscle to 100 lux light stimulus (photopic condition) ${ }^{31}$. Supersensitivity is defined as the intensified function of an effector tissue as a reaction to a stimulus after a certain time of denervation. Physical denervation is not imperative for cholinergic supersensitive behavior of the cholinergic system. If there is any disintegration along the pathway of the neural impulses, it may lead to functional denervation and consequent supersensitivity. Decreased synthesis or secretion of a neurotransmitter from nerve terminals as well as depressed afferent cholinergic impulse to the sphincter muscle of iris under enhanced darkness may lead to functional denervation ${ }^{31}$.

Mesopic pupil sizes seemed bigger in the obese group in our study. This may be attributed to parasympathetic hypoactivity and relative sympathetic hyperactivity in low-luminance conditions.

Total median WF aberrations in obese children were significantly higher. The other aberrations including trefoil, coma, tetrafoil, and spherical aberrations were higher in the obese group though the difference was not statistically significant. This could be influenced by mesopic pupil sizes which were larger in the obese group. It is well known that aberrations are proportional to pupil size therefore; bigger pupil size results in greater aberrations particularly in mesopic conditions.
Our study has potential limitations. As pupillometry is an indirect way of assessing the ANS imbalance; it could be fortified by different techniques that check ANS functions such as heart rate variability, pseudomotor axon reflex, urinary catecholamine levels, tilt table test and skin conductance responses. The number of subjects was limited. Furthermore, our study was conducted in a certain age range; so the results could be more valuable for these ages. Pupillometric readings reflect a moment of time; thus longer recording time including night time may display more precise results. Our study might have been more valuable if the influence of cognitive and emotional tasks were added. Therefore, we suggest that further comprehensive studies should be carried out to enlighten the role of obesity on pupil sizes and WF aberrations in children

In conclusion; this study showed evidence of ANS dysfunction by pupillometry in obese children similar to the previous studies ${ }^{28-30}$. There seems to be an association between obesity and pupillary function and WF aberrations. Our study became original in presenting the first comprehensive assessment of WF aberrations in obese and healthy children. WF aberration alterations in obese children might have been affected by the increase of pupil size in mesopic conditions. These data suggest that obesity may be an important risk factor for aberrations associated with diminished optical quality in children.

\section{Financial Interest}

The authors declare that they have no competing interests. The authors have no relevant financial or nonfinancial relationships to disclose.

\section{References}

1. Collaboration NCDRF. Worldwide trends in body-mass index, underweight, overweight, and obesity from 1975 to 2016: a pooled analysis of 2416 population-based measurement studies in 1289 million children, adolescents, and adults. Lancet 2017;390(10113):2627-42.

2. Malhotra S, Sivasubramanian R, Singhal V. Adult obesity and its complications: a pediatric disease? Curr Opin Endocrinol Diabetes Obes 2021;28(1):46-54.

3. Kaufman CL, Kaiser DR, Steinberger J, Kelly AS, Dengel DR. Relationships of cardiac autonomic function with metabolic abnormalities in childhood obesity. Obesity (Silver Spring) 2007;15(5):1164-71. 
4. Tonhajzerova I, Javorka M, Trunkvalterova Z, Chroma O, Javorkova J, Lazarova Z, et al. Cardio-respiratory interaction and autonomic dysfunction in obesity. J Physiol Pharmacol 2008;59 Suppl 6:709-18.

5. Yadav RL, Yadav PK, Yadav LK, Agrawal K, Sah SK, Islam MN. Association between obesity and heart rate variability indices: an intuition toward cardiac autonomic alteration - a risk of CVD. Diabetes Metab Syndr Obes 2017;10:57-64.

6. Colak R, Donder E, Karaoglu A, Ayhan O, Yalnız M. Obesity and the activity of the autonomic nervous system. Turk $\mathrm{j}$ Med Sci 2000;30(2):173-6.

7. Alkan A, Eker H, Hallioglu O, Citırik D, Parlak E, H. D. Obez ve Spor Yapan Cocuklarda Kalp Hızı Değişkenliğinin Karşılaştırılması. Mersin Unv Sag Bil Der 2013;6(1):8-13.

8. Zahorska-Markiewicz B, Kuagowska E, Kucio C, Klin M. Heart rate variability in obesity. Int J Obes Relat Metab Disord 1993;17(1):21-3.

9. Laederach-Hofmann K, Mussgay L, Ruddel H. Autonomic cardiovascular regulation in obesity. $\mathrm{J}$ Endocrinol 2000;164(1):59-66.

10. Baum P, Petroff D, Classen J, Kiess W, Bluher S. Dysfunction of autonomic nervous system in childhood obesity: a crosssectional study. PLoS One 2013;8(1): e54546.

11. Rabbia F, Silke B, Conterno A, Grosso T, De Vito B, Rabbone I, et al. Assessment of cardiac autonomic modulation during adolescent obesity. Obes Res 2003;11(4):541-8.

12. Chintala KK, Krishna BH, N MR. Heart rate variability in overweight health care students: correlation with visceral fat. J Clin Diagn Res 2015;9(1): Cc06-8.

13. Lambert GW, Schlaich MP, Eikelis N, Lambert EA. Sympathetic activity in obesity: a brief review of methods and supportive data. Ann N Y Acad Sci 2019;1454(1):56-67.

14. Heller PH, Perry F, Jewett DL, Levine JD. Autonomic components of the human pupillary light reflex. Invest Ophthalmol Vis Sci 1990;31(1):156-62.

15. Fotiou F, Fountoulakis KN, Goulas A, Alexopoulos L, Palikaras A. Automated standardized pupillometry with optical method for purposes of clinical practice and research. Clin Physiol 2000;20(5):336-47.

16. Venkata Sivakumar A, Kalburgi-Narayana M, Kuppusamy M, Ramaswamy P, Bachali S. Computerized dynamic pupillometry as a screening tool for evaluation of autonomic activity. Neurophysiol Clin 2020;50(5):321-9.

17. Shirakawa $S$, Ishikawa $S$. [Evaluation of autonomic nervous function by pupil dynamics recording]. Nihon Rinsho 1992;50(4):708-16.
18. Lombardo M, Lombardo G. Wave aberration of human eyes and new descriptors of image optical quality and visual performance. J Cataract Refract Surg 2010;36(2):313-31.

19. Del Aguila-Carrasco AJ, Kruger PB, LaraF,Lopez-Gil N.Aberrations and accommodation. Clin Exp Optom 2020;103(1):95-103.

20. Neyzi O, Gunoz H, Furman A, Bundak R, Gokcay G, Darendeliler $\mathrm{F}$, et al. Türk çocuklarinda vücut ağirliği, boy uzunluğu, baş çevresi ve vücut kitle indeksi referans değerleri. Cocuk Sag Hast Der 2008;51:1-14.

21. Vinik AI, Maser RE, Ziegler D. Autonomic imbalance: prophet of doom or scope for hope? Diabet Med 2011;28(6):643-51.

22. Liao D, Rodriguez-Colon SM, He F, Bixler EO. Childhood obesity and autonomic dysfunction: risk for cardiac morbidity and mortality. Curr Treat Options Cardiovasc Med 2014;16(10):342.

23. Patwari PP, Stewart TM, Rand CM, Carroll MS, Kuntz NL, Kenny AS, et al. Pupillometry in congenital central hypoventilation syndrome (CCHS): quantitative evidence of autonomic nervous system dysregulation. Pediatr Res 2012;71(3):280-5.

24. Meshcheryakov SV, Semenova ZB, Lukianov VI, Sorokina EG, Karaseva OV. Prognosis of Severe Traumatic Brain Injury Outcomes in Children. Acta Neurochir Suppl 2018;126:11-6.

25. Dinalankara DMR, Miles JH, Nicole Takahashi T, Yao G. Atypical pupillary light reflex in 2-6-year-old children with autism spectrum disorders. Autism Res 2017;10(5):829-38.

26. Philby MF, Aydinoz S, Gozal D, Kilic S, Bhattacharjee R, Bandla $\mathrm{HP}$, et al. Pupillometric findings in children with obstructive sleep apnea. Sleep Med 2015;16(10):1187-91.

27. Kara K, Karaman D, Erdem U, Congologlu M, Durukan I, Ilhan A. Investigation of autonomic nervous system functions by pupillometry in children with Attention-Deficit/Hyperactivity Disorder. Klinik Psikofarmakoloji Bül 2013;23(1):49-56.

28. Sekine M, Izumi I, Yamagami T, Kagamimori S. Obesity and cardiac autonomic nerve activity in healthy children: Results of the toyama birth cohort study. Environ Health Prev Med 2001;6(3):149-53.

29. Nagai N, Matsumoto T, Kita H, Moritani T. Autonomic nervous system activity and the state and development of obesity in Japanese school children. Obes Res 2003;11(1):25-32.

30. Yakinci C, Mungen B, Karabiber H, Tayfun M, Evereklioglu C. Autonomic nervous system functions in obese children. Brain Dev 2000;22(3):151-3.

31. Jacobson DM. A prospective evaluation of cholinergic supersensitivity of the iris sphincter in patients with oculomotor nerve palsies. Am J Ophthalmol 1994;118(3):377-83. 